\title{
Regina Lissowska-Postaremczak
}

\section{GRY Z PERCEPCJA \\ O STRATEGIACH KINESTETYCZNEGO ZAANGAŻOWANIA}

Na zachodnich scenach teatru tańca, taniec, sztuka poruszającego się ciała, jest tworzona, by ja oglądać. Sprzeczność polega na tym, że taniec jest tworzony dzięki doświadczeniom poruszających się ciał,

a postrzegany przez widzów przede wszystkim wizualnie.

Jeoren Fabious

W tych słowach Jeoren Fabious (Fabious 2009, s. 331) porusza kluczowe dla tańca zagadnienie dostępności ucieleśnionego doświadczenia ruchu nie tylko dla tancerzy, ale także dla widzów; tańca percypowanego nie tylko zmysłem wzroku, lecz całym ciałem.

$\mathrm{W}$ tradycyjne rozumienie choreografii jako sztuki strukturyzowania tańca wpisana jest określona relacja nadawczo-odbiorcza, oparta na wizualnym oglądzie ruchu. Ten podstawowy paradygmat odbioru i interpretacji tańca długo pozostawał niezmienny. Bazował na jego zauważalnych cechach, czyli czasowych, przestrzennych i dynamicznych właściwościach ruchu. Odwoływał się do kategorii estetycznych (mieszczących w sobie także antyestetykę) oraz zewnętrznych wobec samego tańca odniesieniach semantycznych, będących źródłem jego interpretacji.

Jednak w ostatnim czasie coraz częściej można zaobserwować przykłady praktyk artystycznych, które podważają znaczenie wizualności i interpretacyjności tańca. Zainteresowanie współczesnych twórców kinestetycznym i zmysłowym doświadczeniem ruchu oraz mechanizmami jego percepcji prowadzi do nowych strategii choreograficznych, ukierunkowanych na udostępnienie widzom pozaestetycznych i pozaintelektualnych, a nawet pozawzrokowych obszarów doświadczenia spektaklu. Doznania kinestetyczne bywają w nich tematyzowane lub konceptualizowane oraz wykorzystywane jako (uświadomiony) modus odbioru spektaklu, bądź też modyfikowane w sferze technologicznej. 


\section{Kinestezja}

Kinestezja jest potocznie rozumiana jako „szósty zmysł”, czyli zdolność odczuwania ruchów kończyn i ciała. Nie jest to jednak sam ruch, lecz złożony proces, angażujący działania wszystkich systemów zarządzających doświadczaniem różnych doznań podczas ruchu. Współczesne teorie poświęcone percepcji kinestetycznej podkreślają, że jest ona aktywnym procesem i istotną funkcją poznawczą, współkształtowaną poprzez uwarunkowania kulturowe i społeczne, a także przemiany cywilizacyjne. Prowadzony od końca XIX wieku interdyscyplinarny dyskurs wokół zjawiska kinestezji ożywił się znacznie wraz z odkryciem neuronów lustrzanych, co w ciągu ostatnich dwóch dekad zaowocowało coraz dokładniejszym rozpoznaniem procesów związanych z percepcją kinestetyczną. Rozwój tego dyskursu w perspektywie teorii tańca przedstawia Susan Leigh Foster (Foster 2011), zestawiając go z równoległą ewolucją pojmowania choreografii. Niezależnie od wielości współczesnych naukowych teorii kinestezji i różnic wynikających z perspektyw badawczych upowszechniona świadomość występowania tego zjawiska znacząco wpływa na współczesne pojmowanie ciała, a przez to także jego funkcji w sztuce.

Jednocześnie nowe cyfrowe technologie radykalnie przekształcają system orientacji i funkcjonowanie człowieka w świecie. Coraz szybciej i coraz intensywniej rozwijające się technologie łączności, nawigacji oraz systemów przetwarzania danych, a także ciągłe zanurzenie w otoczeniu coraz bardziej taktylnych technologii ${ }^{1}$ pociągają za sobą nieuniknione zmiany $\mathrm{w}$ funkcjonowaniu ludzkiego ciała i modelu percepcji ${ }^{2}$. Nawyki percepcyjne wykształcone w sieciowym i technologicznym otoczeniu bywają również wykorzystywane przez artystów, którzy czerpią z szeroko pojętych nowych mediów oraz ze strategii interaktywności, komunikacji czy nawigacji mających swoje źródło w Internecie, urządzeniach telekomunikacyjnych i grach komputerowych (Zamorska 2015).

W dalszej części artykułu przybliżę kilka przykładów działań artystycznych realizujących różne strategie percepcyjnego zaangażowania widza, bazujących na doznaniach kinestetycznych i wykraczających poza ugruntowane $\mathrm{w}$ tradycji choreograficznej podejście do „oglądania tańca”. Warto przy tym podkreślić, że działania te nie są jednoznacznie związane z konkretnym stylem, formą czy nurtem tańca, nie są też właściwością konkretnego typu czy formatu wydarzenia. Dlatego też przywołane zostaną przykłady zarówno produkcji pełnowymiarowych spektakli uznanych choreografów, jak i działań o charakterze eksperymentalnym; prezentowanych w tradycyjnej przestrzeni sceny pudełkowej lub w przestrzeniach nieteatralnych; operujących ruchem ustrukturyzowanym albo improwizowanym. 


\section{Blokada wzroku}

Percepcja kinestetyczna stała się tematem spektaklu Borisa Charmatza $L a$ Chaise (2002). Podczas niego jeden z widzów siada na krześle z zasłoniętymi opaską oczami, gdy w tym samym czasie tancerz porusza się bardzo blisko niego. Natychmiast staje się oczywiste, że choć siedząca osoba nie może widzieć, to odbiera ten ruch innymi zmysłami. Cała sytuacja przypomina nieco dziecięcą zabawę. Pozostali, siedzący wokół i obserwujący te działania widzowie, są w ten sposób skłaniani do wyobrażenia sobie tych odczuć - takich jak dźwięk, dotyk czy ruch powietrza wywołany przez poruszające się ciało. Taniec jest $\mathrm{w}$ tym układzie odbierany przez widzów bezpośrednio, poprzez wzrok, oraz pośrednio - poprzez wyobrażenie odczuć siedzącej na krześle osoby.

La Chaise wskazuje, że taniec nie może być zredukowany do wizualnych właściwości; że proces percepcji, w tym przypadku wizualnej, funkcjonuje w obrębie sieci wzajemnie połączonych systemów. Choć temat percepcji kinestetycznej potraktowany jest tu przede wszystkim konceptualnie, tradycyjna relacja dystansu zostaje zastąpiona włączeniem widza w przestrzeń działań i zaangażowaniem innych widzów poprzez jego (realne i wyobrażone) odczucia.

Blokada wzroku - ograniczenie lub całkowite wykluczenie możliwości oglądania, analizowania i interpretowania ruchu - bywa również stosowana w celu pobudzenia percepcji sensorycznej. Ruch i całe otoczenie zaczynają być odbierane innymi niż wzrok zmysłami. Dla twórcy może to stanowić cel sam w sobie, np. gdy spektakl tematyzuje doświadczenie percepcyjne. Może jednak również posłużyć jako jeden $\mathrm{z}$ etapów, przygotowanie widza do dalszego, pogłębionego na poziomie zmysłowym odbioru/uczestnictwa.

Podobny zabieg zastosowała Renata Piotrowska w performansach Towarzystwa Prze-Twórczego Unknown \#1, \#2 i \#3, wprowadzając widzów w przestrzeń spektaklu z zasłoniętymi oczami. Zablokowanie wzroku wzmacnia doznania odbierane innymi zmysłami, przede wszystkim za pomocą dotyku i propriocepcji oraz kieruje uwagę na kinestetyczne doświadczenie. W tym przypadku mechanizm deprywacji sensorycznej został wykorzystany jako sposób przygotowania widzów do uczestnictwa w drugiej części spektaklu, gdzie doznania kinestetyczne były modyfikowane za pomocą projekcji.

Magdalena Zamorska, pisząc o wykorzystaniu mediów w polskim nowym tańcu, włącza te działania w kategorię „zaangażowania immersyjnego”, czyli sensorycznego angażowania widzów poprzez wprowadzanie ich w przestrzeń (wykreowaną np. za pomocą mappingu wideo) jako aktywnych uczestników.

Uwrażliwienie sensoryczne przygotowuje do pełniejszego uczestnictwa w pokazie tanecznym, bazującym na technice improwizacji w kontakcie, któremu towarzyszą obejmujące całą przestrzeń, dezorientujące, a nawet zaburzające poczucie równowagi projekcje audiowizualne (Zamorska 2014, s. 18). 


\section{Uwrażliwienie percepcyjne}

Strategię percepcyjnego uwrażliwienia widza zastosowała Magdalena Ptasznik w performansie Surfing ${ }^{3}$. Opiera się on na badaniu mechanizmów aktywacji i sieci wzajemnych oddziaływań, które powstają między obiektami o różnych właściwościach fizycznych (szczególne znaczenie ma tu zróżnicowanie ich faktury, kształtu i powierzchni) oraz performerką. Każdy z obiektów wprowadzany jest przez performerkę $\mathrm{w}$ przestrzeń w podobny sposób, a następnie poddawany tym samym działaniom (np. obracanie, turlanie, rzucanie, przeciąganie po podłodze itp.), które wykonywane są precyzyjnie, w jednakowym kierunku i z jednakową dynamiką. Surfing nie odwołuje się do kodów semantycznych czy estetycznych. Operuje przede wszystkim na poziomie sensorycznym, dążąc do wywołania określonego doświadczenia percepcyjnego. Wpisuje się on w nurt sztuk performatywnych funkcjonujących poza kodami semantycznymi czy estetycznymi. Kluczem zdaje się tu sensoryczna percepcja i doświadczenie, które - choć w różny sposób - dotyczy zarówno performera, jak i widza.

Wraz z kumulacją obiektów na scenie widz obserwuje zagęszczającą się sieć ich wzajemnych związków i interakcji w przestrzeni. Zostaje poddany sensorycznemu uwrażliwieniu, które można porównać do adaptacji wzroku podczas koncentracji na detalach obrazu. Wyostrzająca się percepcja pozwala z czasem dostrzegać nawet bardzo subtelne zmiany dynamiczne i energetyczne, drobne różnice w reakcjach i wzajemnym oddziaływaniu wszystkich elementów.

Widz pozostaje przede wszystkim obserwatorem działań (nie wchodzi $\mathrm{w}$ bezpośrednią, fizyczną interakcję $\mathrm{z}$ obiektami i performerem), ale warunki fizyczne i otoczenie mają w tym przypadku bardzo duże znaczenie dla jego zaangażowania. Dzięki jednolitej powierzchni (karton) pokrywającej całą podłogę i niewielkiej odległości od przestrzeni działań jest on niejako zanurzony w sieć obserwowanych relacji.

Performans angażuje też w dużej mierze odczucia bliskie synestezji. Na przykład doznania haptyczne (odczucia związane z fakturą różnych powierzchni) odbierane są przez widza nie poprzez zmysł dotyku, lecz przede wszystkim za pośrednictwem wzroku i słuchu. Szczególnie silnym bodźcem wydaje się dźwięk. Odgłosy towarzyszące np. tarciu czy zderzaniu różnych obiektów częściowo „przekazują” informacje dotyczące nie tylko ich faktury, ale też ciężaru.

\section{Redukcja ruchu}

Podobny mechanizm uwrażliwienia kinestetycznego pojawia się $\mathrm{w}$ pracy Meg Stuart Splayed Mind Out (1998). Jest to instalacja performatywna łącząca ruch, tekst oraz projekcje wideo, na których w dużym zbliżeniu pokazywane są fragmenty ciała wykonawców i otaczającej ich przestrzeni. Autorka skrajnie redu- 
kuje przy tym materiał ruchowy i przekaz choreograficzny. Wykorzystuje niemal nieruchome ciało, dążąc do wyeksponowania osobistego, cielesnego doświadczenia wykonawcy; wydobywa ruch, który nie jest produktem kompozycji choreograficznej.

Ciało i kinestetyczne doświadczenie jest centralnym elementem jej pracy, ale nie odnosi się do niego wprost. Zasadniczym celem zdaje się raczej eliminacja „taneczności”, przekroczenie konwencji tworzenia tańca, „języka tańca” i chorograficznej manipulacji. Jednocześnie, skrajnie redukując ruch, paradoksalnie wzmacnia intensywność zaangażowania widza.

Stan zbliżony do bezruchu zawiera w sobie także pewną dynamikę. Pozwala na obserwowanie procesów fizjologicznych - oddechu, tętna - czy odruchów, takich jak mruganie. Ograniczenie fizycznej aktywności wyostrza świadomość kinestetycznego doświadczenia wykonawcy, ale też uwagę widza, skoncentrowanego na obserwacji ledwo zauważalnych zmian. Wydobywa też swego rodzaju potencjalny, czy też wirtualny wymiar ruchu (projektowany np. przez napięcia mięśniowe), który jednak może być odbierany przez obserwatora. Odczucia te zostają wzmocnione właśnie poprzez redukcję i spowolnienie.

To wyostrzenie percepcji widza pozwala też na przekroczenie granic wyłącznie wzrokowego doświadczania - zabarwienia wrażeń wzrokowych cielesnym odczuciem.

Jako przykład może posłużyć choćby ostatnia scena spektaklu, w której tancerka Christine de Smedt powtarza w kółko prostą frazę ruchową: palcem rysuje po swoim ciele linie - od ciała do podłogi i z powrotem do ciała, a jej ruch jest równolegle prezentowany na ekranie w bardzo dużym zbliżeniu. Dotyka różnych powierzchni, tekstur, doświadcza różnic temperatury. Powtarzanie tego ruchu wzmacnia wrażenie; w skupionym na obserwacji tego ruchu widzu wywołuje to doznanie bliskie synestezji - jest on wciągany w odczucie obserwowanego dotyku. Percepcja wzrokowa otwiera więc dostęp do fizycznego odczucia, swego rodzaju „haptycznego oglądania” (Fabiuos 2009, s. 337).

\section{Poszerzenie ruchu w przestrzeni wirtualnej}

Wykorzystanie cyfrowych mediów i nowych technologii w tańcu (i szerzej - w sztukach performatywnych) bywa rozpatrywane raczej w kontekście nowych strategii twórczych, opartych m.in. na modelu interaktywności (Birringer 2003, s. 96). Dla choreografii stanowi jednak również odrębną sferę działań w angażowaniu doznań sensorycznych i percepcji kinestetycznej.

Szeroko stosowaną współcześnie praktyką jest włączanie w obręb spektaklu projekcji ruchomego obrazu - jako uzupełnienie działań scenicznych lub element scenografii, co pozwala, w stosunkowo prosty sposób, radykalnie przekształcić scenę i uzyskać spektakularne efekty wizualne. Wykorzystanie rucho- 
mej projekcji ma jednak jeszcze inny, rzadziej podejmowany w refleksji twórczej czy krytycznej wymiar. Niezależnie od celu i kontekstu zastosowania ruchomej projekcji - czy służy ona jako dynamiczne tło, czy jest równorzędna z działaniem scenicznym; czy jest to obraz figuratywny, czy nie - z perspektywy wizualnego oddziaływania na widza jest to przede wszystkim ruch. Musi być zatem rozpatrywany nie tylko w kategoriach projektowanego obrazu, lecz jako komponent dynamiczny/ruchowy spektaklu. Rzutowany ruchomy obraz może oddziaływać w szerokim spektrum doznań kinestetycznych, zależnie od układu następujących zmiennych ruchu: m.in. prędkości, przyspieszenia czy kierunku.

Zasadniczo mamy do czynienia z wektorami, których wartości i współrzędne zmieniają się stale. Ale w ramach całościowej sceny, fragmentarycznej lub fuzyjnej, wektory ruchomych obrazów łączą się z ruchami wykonawcy. Wszystkie te wektory są skuteczne pod względem kinestezji, niezależnie od „świata” (wirtualnego lub materialnego), do którego należą (Boucher 2004).

Zagadnienie to rozwija Marc Boucher, rozpatrując kinestetyczne odziaływanie rzutowanych ruchomych projekcji w kategoriach „kinetycznej synestezji”:

Synestezja kinetyczna dotyczy wizualnych i proprioceptywnych połączeń wzajemnych oraz sposobu, w jaki wizualnie postrzegane wektory ruchu mogą być doświadczane jako kinestezja. Wektory ruchu powstałe w wyniku kombinacji tańca i ruchomych obrazów w scenografii multimedialnej różnią się zasadniczo od tych, które przynależą do tych mediów z osobna. Efekt, jaki zapewniają one wspólnie, ma składową synestezji, ponieważ integruje w percepcyjnej syntezie lub Gestalcie materialne ruchy tańca i wirtualne ruchy obrazu. Kinetyczna synestezja różni się od kinestezji, gdyż wynika ona $\mathrm{z}$ dynamicznych napięć pomiędzy figurą a ziemią (Boucher, 2004).

Przykładem zastosowania strategii choreograficznej polegającej na celowym wykorzystaniu tego kinestetycznego oddziaływania rzutowanego ruchu jest m.in. spektakl BIPED (1999), prezentowany do dziś przez Merce Cunningham Dance Company i powszechnie uznawany za przełom w integracji tańca i technologii ${ }^{4}$.

$B I P E D$ to poszerzona cyfrowa animacja stworzona przez Paula Kaisera i Shelley Eshkar jako wizualny komponent spektaklu skorelowany z choreografią Merce’a Cunninghama i wykonywana przez jego zespół. Nieustannie zmieniająca się projekcja jest rzutowana na ogromną przeźroczystą przesłonę umieszczoną przed sceną. Stwarza to iluzję trójwymiarowego obrazu unoszącego się przed tancerzami i wokół nich. Projekcja, bazująca w dużej mierze na zarejestrowanych za pomocą motion capture fragmentach choreografii, pozwoliła uzyskać efekt nakładania się obrazów realnych i wirtualnych, przypominających świetliste kontury postaci „tańczących” w wolnych przestrzeniach sceny. W przeciwieństwie do tańca projekcja nie jest ciągła - obrazy pojawiają się i znikają w sposób dla wi- 
dza przypadkowy, nieprzewidywalny, niezwiązany przyczynowo z wykonywaną choreografią.

Co istotne, rzutowanie obrazu na przesłonę pozwoliło uzyskać efekt „zanurzenia" tancerzy w wirtualnej przestrzeni, ale przy tym sam projektowany ruch również odbywa się „w trzech wymiarach” (kontury postaci „przybliżają się” i „oddalają”), co powoduje ciągłe zmiany wielkości zajmowanej przestrzeni i skali - są nawet kilkukrotnie większe w stosunku do realnych tancerzy. Niezależnie od rozmiaru ruch konturów postaci (stworzony na podstawie zarejestrowanego wcześniej ruchu tancerzy) przekazuje podobne „ludzkim” kinestetyczne wrażenia - związane z ciężarem, dynamiką czy rotacją stawów.

$\mathrm{Na}$ widza oddziałują więc kinestetycznie równoległe i konkurujące ze sobą dynamiczne bodźce wizualne: tańczące ciało (3D) i rzutowany obraz (2D). Dzięki wrażeniom kinestetycznym doświadczamy iluzji przestrzennych interakcji obu tych wymiarów. Innym, lecz podobnie przełomowym przykładem zastosowania tej strategii był spektakl Klausa Obermaiera Apparition (2004), tworzony we współpracy z artystami z Ars Electronica Futurelab oraz dwojgiem tancerzy (Desirée Kongerd i Robertem Tannionem), odpowiedzialnych za warstwę choreograficzną. Punktem wyjścia była dla Obermaiera chęć opracowania w pełni interaktywnego systemu, dzięki któremu tworzona komputerowo wizualizacja jest nie tylko tłem tańca, lecz równorzędnym partnerem dla wykonawców. Apparition był jednym z pierwszych spektakli bazujących na interaktywnym sprzężeniu rzutowanego ruchomego obrazu z ruchem tancerzy, którym w ten sposób powierzona została kontrola nad wirtualnie kreowanym otoczeniem. System stworzony na potrzeby spektaklu był wynikiem pionierskich wówczas badań prowadzonych przy wsparciu uniwersytetu w Osace i opierał się na wykorzystaniu kamer podczerwieni, które pozwalały na rejestrowanie ruchu w trzech wymiarach oraz przetwarzanie tych danych na cyfrowy obraz ${ }^{5}$. Warto wspomnieć, że podobne możliwości oferuje powszechnie dostępny system „Kinect” (sensor laserowy $\mathrm{z}$ wbudowaną kamerą i mikrofonami emitujący promienie podczerwone, wprowadzony jako kontroler do konsoli Xbox 360 w 2010 r.), co znacząco wplynęło na upowszechnienie wśród artystów tego rodzaju interaktywnych strategii.

Apparition składa się z serii obrazów, w których dynamika i jakość ruchu tancerzy zostają rozszerzone i przeniesione do świata wirtualnego. Relacja między wykonawcami a projekcją stale się zmienia. Chwilami obraz nałożony na ciało (mapping 3D) całkowicie je „wchłania”, optycznie zaciera jego kształt i granice, a nawet wizualnie sprowadza je do dwuwymiarowych, graficznych form. Kiedy indziej projekcja się wycofuje, pozostawiając scenę „realnym” tancerzom i ich abstrakcyjnej choreografii; poprzez kontrast poczucie realności ciała i ruchu zdaje się wtedy uwypuklone. Ciągle zmienna relacja nakładających się dwu- i trójwymiarowych ruchomych obrazów silnie oddziałuje na doznania wzrokowe i manipuluje doznaniami kinestetycznymi. 


\section{Poszerzenie ruchu w sferze dźwięku - udźwiękowienie ruchu}

Strategie odwołujące się do oddziaływania wizualnego, modyfikowania percepcji ruchu tancerza za pomocą projekcji lub mappingu należą do najczęściej dziś realizowanych na styku tańca i nowych technologii. Jednak modyfikacje te nie muszą zachodzić na polu obrazu. Ostatnia z omawianych tu strategii kinestezyjnych opiera się na poszerzeniu ruchu w sferze dźwięku (udźwiękowienia czy też sonifikacji ruchu), prowadzącego do swego rodzaju „transpozycji doznan” w percepcji tańca. Różnego rodzaju poszerzenia ruchu w sferze dźwięku realizowane są dzięki możliwościom nowych mediów, pozwalających na integrację różnego typu czujników i niemal nieograniczonych możliwości dalszego przetwarzania pozyskanych danych w czasie rzeczywistym - również na dźwięk. Przykładem zastosowania tej strategii w choreografii jest Re-mapping the body (2012) szwajcarskiej grupy Cie Linga. Remapowanie ciała to w zamyśle pomysłodawców (Katarzyny Gdaniec i Marco Cantalupo) całkowite odwrócenie tradycyjnego związku między muzyką a choreografią - można więc dosłownie usłyszeć taniec i zobaczyć muzykę. Bezprzewodowe czujniki fizjologiczne, które tancerze zakładają na różne części ciała, pozwalają na rejestrowanie przestrzennych i dynamicznych właściwości ruchu oraz przetwarzanie ich w czasie rzeczywistym na ścieżkę dźwiękową spektaklu. Co ciekawe, oprócz zmian położenia i dynamiki, czujniki rejestrują również zmiany w natężeniu pracy mięśni ciała oraz czynniki takie jak przyspieszone tętno, oddech czy zmiany temperatury. Monitorują więc nie tylko stan fizyczny ciała w ruchu, ale też jego stan fizjologiczny oraz pośrednio - poziom emocjonalny doświadczenia tancerza. System ten w pewnym sensie czyni z wykonawcy rodzaj somatycznego interfejsu, który w sposób interaktywny pozwala uzewnętrznić doświadczenie ciała w ruchu i przenieść je - jako przetworzone dane - $\mathrm{w}$ sferę dźwięku'

Podobny pomysł udźwiękowienia ruchu towarzyszył twórcom spektaklu AUDFIT (2013; Patryk Lichota, Marta Romaszkan i Krystian Klimowski). Improwizacja tancerki jest rejestrowana przez swego rodzaju „dźwiękowy kostium”, składający się z akcelerometrów i czujników ruchu. Sygnały zbierane z dziewięciu strategicznych punktów orientacji ciała w przestrzeni są następnie komputerowo przetwarzane na dźwięk i przesyłane trójpasmowo do słuchawek (Silent Disco), w które widzowie są zaopatrywani przy wejściu. Taniec staje się „instrumentem”; każde poruszenie ciała generuje w czasie rzeczywistym sekwencję dźwiękową.

Ponadto przełączniki umożliwiają wybór spośród trzech rodzajów brzmienia, z których każde inaczej definiuje obserwowany ruch. Przestrzeń dźwiękowa zwrotnie oddziałuje na doznania kinestetyczne. Warto przy tym zaznaczyć, że AUDFIT realizuje jednocześnie strategię interaktywności, nie tylko na poziomie relacji wykonawcy z technologicznym otoczeniem, ale też na poziomie odbior- 
czym - pozwala widzowi na samodzielną nawigację w przestrzeni dźwiękowej - tym samym staje się on programatorem własnej audiowizualnej percepcji.

W kontekście relacji ruchu i dźwięku warto przywołać jeszcze jeden eksperymentalny projekt autorstwa Lichoty pt. Echo Clickers. Był to pokaz performatywny zrealizowany w ramach projektu Friv Move ZAMEK. Trzy tancerki (Joanna Gronek, Marta Romaszkan i Krystyna Szydłowska) poruszały się w przestrzeniach poznańskiego CK Zamek z zasłoniętymi oczami, wyposażone w kinetyczne głośniki zamontowane na ciele. System dźwiękowy zaprojektowany przez Lichotę funkcjonował jako przedłużenie ich zmysłów i umożliwiał im orientację w przestrzeni dosłownie na zasadzie echolokacji. Do głośników przesyłane były w czasie rzeczywistym dane dźwiękowe skorelowane z ruchem ciała i jego odległością od innych obiektów. Ciała wyposażone w dźwiękowe echolokatory wysyłały impulsy, „kreśląc” akustyczne wektory ruchu. Sygnały te były na żywo moderowane i przetwarzane w muzykę, a następnie przesyłane z powrotem i transmitowane za pomocą głośników. Koncepcja Echo Clickers była oparta na literalnym potraktowaniu pojęcia „dźwięku przestrzennego”. Dla widzów pokaz przybierał formę dźwiękowo-ruchowego „koncertu”, podczas którego źródła dźwięku były ruchome i otaczały publiczność. Kinestetyczne doznania tancerek podlegały natomiast reorientacji, dźwięk stawał się ekwiwalentem błędnika. Autor spektaklu tak opisuje powstałą modyfikację dźwiękowo-przestrzennej reorientacji ruchu:

W Echo Clickers istotny jest dźwięk jako informacja o przestrzeni. To on reguluje choreografię powstającą w czasie rzeczywistym, na którą wpływ mają moje decyzje dźwiękowe jako realizatora transmisji dźwiękowych. Tancerki poruszają się według ustalonego kodu dźwiękowego - sygnałów ostrzegawczych, jak również same ustawiają membranę głośnika, celując $\mathrm{w}$ różne punkty przestrzeni, przez co uzyskują informację o swoim położeniu. To buduje $\mathrm{w}$ ich umysłach bardzo różne mapy środowiska, a te przestają być jedną wersją, do której można się odnieść, stając się szeregiem dynamicznie zmieniających się inwariantów, modulacji. (...) Przestrzeń opisywana akustycznie stawała się wirtualną nakładką na tę realną, wyznaczając osie orientacji, wprowadzając wektory przesunięć, zniekształcając pieczołowicie budowane wyobrażenie o miejscu pokazu. Każda decyzja dźwiękowa wyzwalała łańcuch asocjacji ruchowych wszystkich tancerek, na nowo je aktualizując. (...) Dźwięk i jego nieodzowny komponent, czyli przestrzeń, są w sposób podstawowy, niemal wyłączny, modulatorami ruchu. Ruch u tancerki zostaje obdarty z wszelkich wizualnych naleciałości, gdyż konstytuowany jest wyłącznie słyszeniem i słuchaniem (Lichota 2016, s. 221-222).

\section{Podsumowanie}

Opisane tu strategie ukierunkowane są na wzmocnienie kinestetycznego zaangażowania widza oraz uświadomione doświadczanie percepcyjne, które w pewnym sensie może też mieć wymiar synestezyjny. Przywołane spektakle 
prezentują jedynie kilka spośród różnorodnych sposobów, w jakie poziom sensorycznej percepcji może być włączany w koncepcję, strukturę i dramaturgię spektakli tanecznych. W tym kontekście subiektywne i unikatowe sensoryczne doświadczenie staje się nową kategorią artystycznej wartości, niezależną od kategorii estetycznych czy semantycznych i mogącą je zastąpić. Koncentracja na kinestetycznym doświadczeniu tańca nie musi oczywiście wykluczać zaangażowania intelektualnego $\mathrm{w}$ recepcji spektaklu (często stanowi po prostu jego uzupełnienie), nie musi też zaprzeczać semantycznej interpretacji. Przekracza jednak ugruntowaną w tańcu wizualność i redefiniuje model funkcjonowania choreografii.

\section{Bibliografia}

Birringer J. (2003), Dance and Interactivity, „Dance Research Journal” (2), 35/36.

Boucher M. (2004), Kinetic Synaesthesia: Experiencing Dance in Multimedia Scenographies, „Contemporary Aesthetics”, nr 2.

Fabious J. (2009), Seeing the body move, [w:] J. Buttrworth, L. Wildschut (red.), Contemporary Choreography. A Critical Reader, Routledge, London.

Foster S.L. (2011), Choreographing Empathy. Kinesthesia in Performance, Routledge, London-New York.

Lichota P. (2016), Tradycje hałasu w świecie dźwięku, Bogucki Wydawnictwo Naukowe, Poznań.

Zamorska M. (2014), Multimedialność: strategie wykorzystywania nowych mediów (elektronicznych, cyfrowych) $w$ polskim nowym tańcu, Projekt badawczy zrealizowany w ramach III edycji programu „Muzyczne Białe Plamy”, http://imit.org.pl/uploads/materials/files/Zamorska\%20Magdalena\%20-\%20Praca\%20badawcza\%20MBP\%20 III.pdf (dostęp: 27.07.2017).

\section{Summary}

The article deals with choreographic strategies that challenge the dominance of visuality and interpretative in dance. The preoccupation of contemporary choreographers with the kinesthetic experience of the moving body and the mechanism of perception leads to new choreographic strategies aiming to make non-aesthetic and non-intellectual, and even non-visual areas of the spectacle experience accessible for a viewer.

The author give examples of choreographic works that implement various strategies of perceptual engagement of the viewer, based on kinesthetic experiences and crossing the traditional audience-viewer relation that involves mainly visual access to movement. The kinesthetic experience became a subject matter of dance performance, or is conceptualized, used as (conscious) mode of reception of the spectacle, or modified in the technological field. 


\section{Przypisy}

1 Ang. tactile technologies - technologie związane z tworzeniem urządzeń dotykowych, intuicyjnych interfejsów i systemów nawigacji.

2 Zagadnienie to rozwija Agnieszka Jelewska, opisując zjawiska kształtujące zmysłową rzeczywistość współczesnąi implementującje do refleksji nad sztukąi percepcją sztuki. Jelewska A. (2012), Sensorium. Eseje o sztuce i technologii, Wydawnictwo Naukowe UAM, Poznan.

3 Performans zrealizowany w Art Stations Foundation w ramach programu rezydencyjnego Solo Project 2012. Dramaturgia: Eleonora Zdebiak. Szerzej opisany został przeze mnie w ramach projektu „Badanie/Produkcja - rezydencje. Taniec w procesie artykulacji”, www.taniecpolska.pl/krytyka/241 (dostęp: 28.07.2017).

4 Szczegółowo o wykorzystanej w BIPED technologii i procesie jej powstawania pisze Paul Kaiser (1999), On BIPED, http://openendedgroup.com/artworks/biped_essay.html (dostęp: 28.07.2017).

5 Więcej o systemie zaprojektowanym na potrzeby spektaklu Apparition: www.exile. at/apparition/project.html (dostęp: 28.07.2017).

6 Zarówno Apparition, jak i Re-mapping the body zostały zaprezentowane w Polsce podczas 17. Międzynarodowych Spotkań Teatrów Tańca w Lublinie. Oba spektakle opisywałam wcześniej w recenzji: Re-mediacje, e-teatr 26.11.2013, www.e-teatr.pl/ $\mathrm{pl} /$ artykuly/173510.html (dostęp: 28.07.2017). 